\title{
EFEKTIVITAS VIDEO PEMBELAJARAN MATEMATIKA PADA MATERI DIMENSI TIGA DENGAN MENGGUNAKAN PEN TABLET
}

\author{
EVI MAFIDAH \\ MAN 1 Tuban \\ e-mail: mafidahevi@gmail.com
}

\begin{abstract}
ABSTRAK
Kebijakan pemerintah yang mengubah pembelajaran tatap muka menjadi daring menuntut kreatifitas dan inovasi guru sehingga hak peserta didik dapat terpenuhi selama proses belajar. Sementara hasil observasi selama pandemi sebagian besar guru menggunakan bahan ajar berupa PPT MS.Word maupun PDF sederhana,sehingga membuat peserta didik merasa bosan karena belum mampu memahami meteri dengan benar tanpa adanya penjelasan dari guru. Fenoma tersebut yang menjadikan motivasi untuk mengembangkan media pembelajaran dalam bentuk Video berbasis Pen Tablet. Best practise ini disusun dengan tujuan untuk mendeskripsikan praktek baik dalam melaksanakan pembelajaran jarak jauh meggunakan video pembelajaran berbasis Pen tablet pada materi dimensi tiga di MAN 1 Tuban. Praktek terbaik dilaksanakan pada semester ganjil tahun pelajaran 2021/2022 yaitu bulan Juli sampai Agustus 2021. Karya ilmiah ini mengggambarkan tentang peningkatan kehadiran siswa, nilai rata rata ulangan harian dan respon siswa terhadap video. Adapun subyek penelitian yaitu peserta didik kelas XII IPS dan XII IPA di MAN 1 Tuban Kecamatan Semanding Kabupaten Tuban sebanyak 112 siswa dengan membawa perubahan yang signifikan yaitu kehadiran siswa sebelum menggunakan video mencapai $61.61 \%$,setelah mengggunakan video berbasis Pen Tablet sebesar $83.92 \%$, sedangkan rata rata nilai ulangan yang dicapai rata rata di atas KKM yaitu 77 dan respon terhadap video sebanyak 138 kali ditonton.
\end{abstract}

Kata Kunci: Video Pembelajaran, Dimensi Tiga, Pen Tablet

\section{PENDAHULUAN}

Sejak pemerintah mengumumkan kasus Covid-19 di Indonesia pada Bulan Maret 2020 lalu. upaya merubah pandangan siswa terhadap matematika bahwa matematika itu asyik menjadi lebih sulit. Hal ini dikarenakan masyarakat dihimbau melakukan sosial distancing, dimana semua kegiatan harus dilakukan di rumah tidak terkecuali proses pembelajaran matematika. Sistem pembelajaran tatap muka di kelas dirubah menjadi pembelajaran jarak jauh atau daring agar proses pembelajaran tetap berlangsung sehingga terpenuhi hak peseta didik dalam belajar, yang dikutip dari (Apriyanto, M.T. \& Herlina, L, 2020). Untuk mengatasi hal tersebut maka Menurut Fadhli (dalam Hamdan, H. \& Dessy, N, 2016). Salah satu cara untuk menghasilkan proses pembelajaran matematika yang menarik adalah dengan memanfaatkan video sebagai sumber dan media pembelajaran. Putri (2012), juga mengemukakan bahwa Pembelajaran yang dilakukan dengan media video membuat anak lebih efektif bisa menerima pembelajaran yang diberikan kepadanya. Oleh karena itu, pemerintah dan guru-guru telah banyak menggunakan video sebagai media dan sumber belajar di masa Pandemi Seperti penggunaan video pembelajaran dalam situs TV edukasi, Youtube, e-learning dan lain sebagainya. Berbagai hasil penelitian juga menunjukkan bahwa orang lebih tertarik belajar menggunakan media video daripada belajar melalui media teks dan gambar diam

Hasil observasi selama Masa Pandemi covid-19, Sebagian besar guru di MAN 1 Tuban masih mengandalkan bahan ajar berupa PPT MS.Word maupun PDF sederhana yang dikirim ke Whashap grup kelas dan elearning. Dimana bahan ajar tersebut berisi materi singkat. Terkadang peserta didik merasa bosan karena belum mampu memahami meteri dengan benar tanpa adanya penjelasan dari guru. Akibat feomena ini, sebagian besar motivasi belajar peserta didik khususunya di MAN 1 menurun drastis. Sehingga berakibat pula terhadap penurunan pencapaian hasil belajar yang rata rata di bawah Kompetensi Kecapaian Minimal. Oleh karena itu selama proses pembelajaran daring peran guru sangat penting untuk memberikan motivasi 
dengan cara berbeda. Tidak ada salahnya guru membuat inovasi PPT dengan dukungan video tutorial dengan menggunakan alat Pen Tablet, sehingga peserta didik merasa senang belajar matematika dengan didampingi guru atau tidak didampingi guru. Tentunya hal ini tidak mudah, selain kompetensi wajib harus dimiliki, seorang guru harus memiliki kreativitas meramu pembelajaran dalam kelas jarak jauh agar tidak monotan. Selain itu guru pun harus memiliki kompetensi pendukung dalam bidang teknologi untuk membantu mengembangkan media pembelajaran berbasis tekonologi yang sangat membantu tugas pokok guru dalam proses pembelajaran yang dilakukan secara jarak jauh ( daring) dengan memanfaatkan media internet.

Mencermati hal tersebut maka perlu inovasi bahan ajar E-learning untuk menjawab permasalahan tersebut. Jika selama ini bahan ajar identik dengan buku dan PPT, maka salah satu inovasi yang dapat dilakukan adalah dengan menyediakan bahan ajar berbentuk video. Selain memudahkan siswa dalam memahami materi dibandingkan melalui PPT dan buku teks, video pembelajaran juga dapat ditonton berulang kali. Sehingga ketika siswa lupa dengan suatu materi, mereka dapat memutar kembali video pembelajaran yang dikutip dari Marfi (dalam Ario, 2019). Selain itu video pembelajaran juga memberikan keuntungan lain, yaitu siswa dapat mempelajari suatu materi dengan kecepatan belajar masing-masing, karena video pembelajaran dapat dijeda (pause) untuk mencatat hal-hal penting dan dilanjutkan kembali oleh siswa sesuai kebutuhan masing-masing di kutip dari (Anggraeni dkk., 2019).

\section{METODE PELAKSANAAN}

Inovasi video pembelajaran sebagai alternatif dalam pembelajaran jarak jauh dipilih oleh penulis sebagai praktek terbaik pada masa pandemi covid -19 . Best practice dilaksanakan karena mampu memberikan perubahan bagi peserta didik dengan metode yang bersifat efektif dan efesien. Data yang digunakan dalam best practice ini adalah data-data dari jejak pelaksanaan kegiatan yang telah dilalui berupa hasil dokumentasi keaktifan siswa (absensi), respon siswa terhadap video pembelajaran, video pembelajaran dan daftar nilai. Best practice digambarkan dalam bentuk tabel dan grafik.

Praktek baik ini dilaksanakan di kelas XII IPS dan XII IPA berjumlah 112 siswa pada semester ganjil tahun pelajaran 2021/2022 yaitu mulai tgl 30 Juli sampai dengan 14 Agustus 2021. Tempat pelaksanaan best practice adalah MAN 1 Tuban, Jalan HOS Cokroaminoto No 4 Tuban Selatan. Bahan yang digunakan untuk best practice adalah video pembelajaran berbasis Pen Tablet yang berkaitan dengan pelajaran Matematika Wajib materi dimensi tiga di kelas XII semester ganjil.

\section{HASIL DAN PEMBAHASAN}

Inovasi video dalam best practise ini merupakan video yang menampilkan materi dimensi tiga dalam rangkaian slide-slide powerpoint yang diatur menurut durasi dan animasi yang telah ditentukan. pengembangan videonya dibuat dengan langkah-langkah sebagai berikut; (1). materi pelajaran disajikan dalam bentuk slide powerpoint sebagaimana membuat presentasi pada umumnya,(2) setiap slide ditambahkan animasi yang sesuai pada objek dan transisi slide sehingga materi pelajaran tampil secara berurutan dan tampak lebih menarik (3) Simpan dokumen PowerPoint dalam format video dengan cara klik tab file, klik Export, klik Create a video, klik menu "Presentation Quality" untuk menentukan kualitas video, klik "Record Timing \& Narations"untuk merekam suara presenter dan menentukan durasi waktu berjalannya sebuah slide powerpoint, klik "Start Recording" untuk mulai merekam, jalankan dan jelaskan isi presentasi Anda dengan sistematis dan tenang dengan menggunakan Pen tablet, kemudiaan dijalankan dan dijelaskan isi presentasi dengan sistematis dan tenang dengan menggunakan Pen Tablet dan ini didukung hasil penelitian dari (Maharani, N. 2021; Hamdan, H. \& Dessy, N. 2016; Carrillo Andrés, at al., 2013).

Materi Dimensi tiga dalam best practise ini adalah Objek-objek seperti titik, garis, bidang, kubus, balok, bola, dan sebagainya atau objek-objek yang didapatkan melalui proses abtraksi berdasarkan benda-benda konkret yang terdapat dalam kehidupan sehari-hari 
Sehingga, sangat diharapkan bagi pendidik maupuan guru dalam mengembangkan pemahaman siswa pada konsep geometri sebaiknya dilakukan dengan aktivitas manipulasi objek-objek spasial atau benda-benda nyata (pengalaman kongkrit), brainstroming (konsep perumpamaan) sampai akhirnya siswa akan memiliki pengetahuan yang bersifat abstrak. Hal ini sesuai dengan hasil penelitian (Novita. R, et al.2018). Adapun Pen Tablet yaitu suatu alat yang memungkinkan pengajar untuk menyertakan konten informasi seperti tabel, grafik, simbol-simbol matematika dan diagram yang rumit, dimungkinkan juga untuk menandai slide, membubuhi keterangan pada gambar atau memberikan komentar. Hal tersebut menjadi salah satu metode yang sangat baik untuk berkomunikasi secara visual dengan siswa dan meningkatkan pemahaman mereka. Pengajar juga dapat menyimpan materi yang telah dituliskan pada tiap pertemuan, sehingga menjadi bahan evaluasi atau menjadi pengingat dan batas untuk pertemuan selanjutnya. Hal ini tentunya sangat berbeda ketika pengajar menggunakan papan ajar konvensional.

Best practise ini disusun untuk mendapatkan gambaran tentang kebutuhan pembelajaran daring dengan bahan ajar video berbasis pen tablet .Pernyataan-pernyataan yang terkait dengan pengembangan video dengan menggunakan pen tablet dalam kegiatan pembelajaran antara lain data absensi siswa, Respon terhadap bahan ajar video dan penilaian harian.

1. Populasi data yang dipergunakan dalam best praktise ini adalah hasil rekapitulasi jumlah absensi siswa dalam kurun waktu 2 bulan yaitu bulan Juli 2021 sampai dengan Agustus 2021. Populasi berikut ini merupakan data awal yang akan dipergunakan sebagai dasar. Adapun Populasi data tersebut dapat dipaparkan sebagai berikut

Tabel 1. Populasi Siswa Per kelas

\begin{tabular}{lllcc}
\hline No & Bulan & Kelas & Jumlah Siswa & Ket \\
\hline 1 & Juli-Agustus 2021 & XII MIPA 4 & 29 & \\
2 & Juli-Agustus 2021 & XII MIPA 5 & 27 & \\
3 & Juli-Agustus 2021 & XII IPS 1 & 27 & \\
4 & Juli-Agustus 2021 & XII IPS 5 & 29 & \\
& Jumlah & & 112 & \\
\hline
\end{tabular}

Tabel 2. Data Jumlah Ketidakhadiran Per Kelas sebelum menggunakan video

\begin{tabular}{|c|c|c|c|c|c|c|c|}
\hline \multirow{2}{*}{ No } & \multirow{2}{*}{ Bulan } & \multirow{2}{*}{ Kelas } & \multicolumn{3}{|c|}{ Jumlah Absensi ( \% ) } & \multirow{2}{*}{$\begin{array}{l}\text { Total } \\
(\%)\end{array}$} & \multirow{2}{*}{ Ket } \\
\hline & & & $S$ & I & $\mathrm{A}$ & & \\
\hline 1 & Juli-Agustus 2021 & $\begin{array}{l}\text { XII MIPA } \\
4\end{array}$ & 2 & 2 & 14 & 18 & \\
\hline 2 & Juli-Agustus 2021 & $\begin{array}{l}\text { XII MIPA } \\
5\end{array}$ & 1 & 2 & 17 & 20 & \\
\hline 3 & Juli-Agustus 2021 & XII IPS 1 & 2 & 3 & 15 & 20 & \\
\hline \multirow[t]{2}{*}{4} & Juli-Agustus 2021 & XII IPS 5 & 1 & 3 & 17 & 21 & \\
\hline & Jumlah & & 6 & 10 & 63 & 79 & \\
\hline
\end{tabular}

Tabel 3. Data Jumlah Ketidakhadiran Per Kelas setelah menggunakan video

\begin{tabular}{lllccccc}
\hline \multirow{2}{*}{ No } & Bulan & Kelas & \multicolumn{2}{c}{ Jumlah Absensi (\%) } & \multicolumn{2}{c}{ Total } & Ket \\
\hline 1 & Juli-Agustus 2021 & $\begin{array}{l}\text { XII MIPA } \\
4\end{array}$ & 1 & 2 & 3 & 6 & \\
2 & Juli-Agustus 2021 & $\begin{array}{l}\text { XII MIPA } \\
5\end{array}$ & 0 & 2 & 4 & 6 & \\
3 & Juli-Agustus 2021 & XII IPS 1 & 0 & 2 & 5 & 7
\end{tabular}




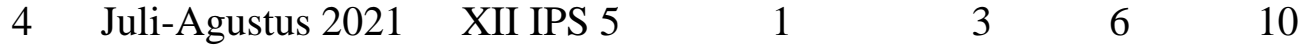

Jumlah

2

$9 \quad 18$

29

Tabel 4. Data jumlah kehadiran sebelum dan setelah penggunaan video

\begin{tabular}{|c|c|c|c|c|c|}
\hline \multirow[b]{2}{*}{ No } & \multirow[b]{2}{*}{ Bulan } & \multicolumn{4}{|c|}{ Jumlah Absensi ( \% ) } \\
\hline & & Kelas & $\begin{array}{c}\text { Sebelum } \\
\text { penggunaan } \\
\text { video }\end{array}$ & $\begin{array}{c}\text { Setelah } \\
\text { penggunaan video }\end{array}$ & Ket \\
\hline 1 & $\begin{array}{l}\text { Juli-Agustus } \\
2021\end{array}$ & $\begin{array}{l}\text { XII MIPA } \\
4\end{array}$ & 18 & 6 & terlihat \\
\hline 2 & $\begin{array}{l}\text { Juli-Agustus } \\
2021\end{array}$ & $\begin{array}{l}\text { XII MIPA } \\
5\end{array}$ & 20 & 6 & $\begin{array}{l}\text { perubahan } \\
\text { jumlah }\end{array}$ \\
\hline 3 & $\begin{array}{l}\text { Juli-Agustus } \\
2021\end{array}$ & XII IPS 1 & 20 & 7 & $\begin{array}{l}\text { ketidakhadiran } \\
\text { setelah }\end{array}$ \\
\hline 4 & $\begin{array}{l}\text { Juli-Agustus } \\
2021\end{array}$ & XII IPS 5 & 21 & 10 & $\begin{array}{l}\text { menggunakan } \\
\text { video }\end{array}$ \\
\hline & Jumlah & & 79 & 29 & \\
\hline
\end{tabular}

Rekapitulasi ketidakhadiran peserta Didik pada pembelajaran daring dengan pemanfaatan media pembelajaran yang berbasis video dapat dilihat dari gambar grafik 1 di bawah ini yang. Grafik batang yang berwarna biru menunjukkan jumlah peserta didik yang absen sebelum penggunaan video dan yang berwarna merah menunjukkan jumlah peserta yang absen setelah penggunaan video dari masing masing kelas yaitu kelas XII MIPA 4, XII MIPA 5, XII IPS 1 dan XII IPS 5. Grafik tersebut menunjukkan adanya peningkatan absen peserta didik sesudah penggunaan video. Sehingga dapat dikatakan bahwa proses pembelajaran jarak jauh yang dilakukan dengan mengembangkan video berbasis Pen Tablet dengan elearning dan WA grup kelas sebagai kelas virtual berlangsung aktif.

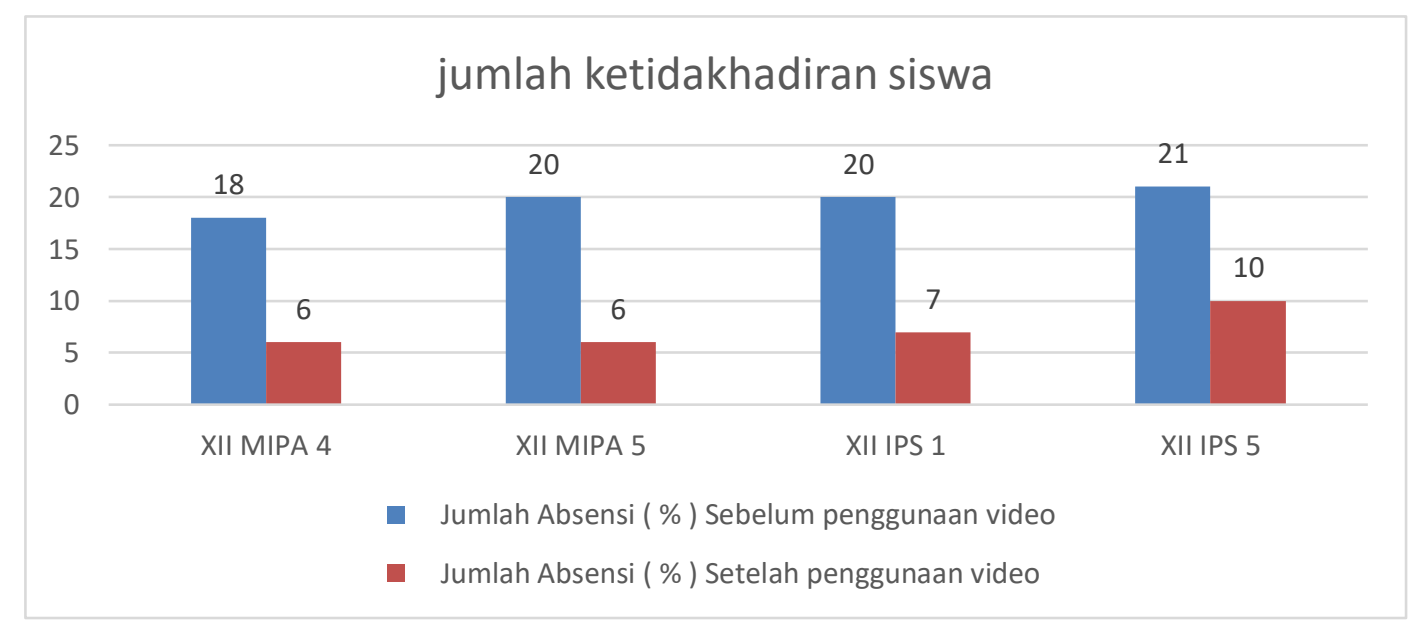

Gambar 1. Absensi ketidakhadiran siswa 
2. Inovasi video pembelajaran menggunaka Pen Tablet, saat ini sudah mulai digunakan dalam pembelajaran khususnya pembelajaran jarak jauh. Bila digabungkan dengan kanvas digital sebagai media menulis di komputer dan direkam menggunakan video screen akan menghasilkan video yang baik, karena dapat diputar ulang sesuai kebutuhan seperti video materi dimensi tiga pada Gambar 2. dan Gambar 3.

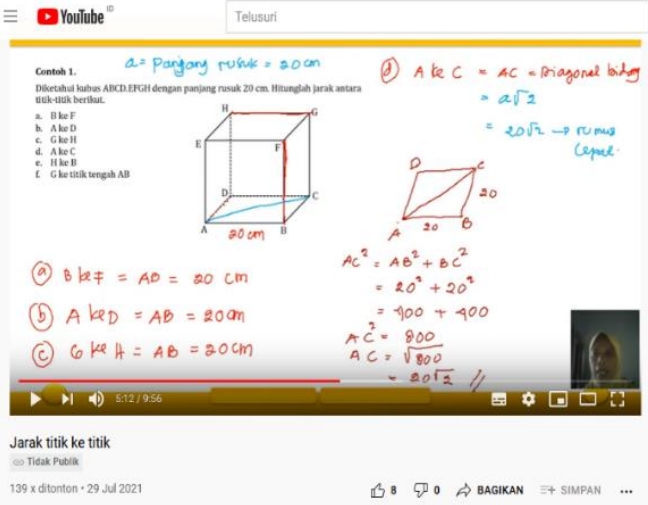

Gambar 2. Video jarak titik ke titik

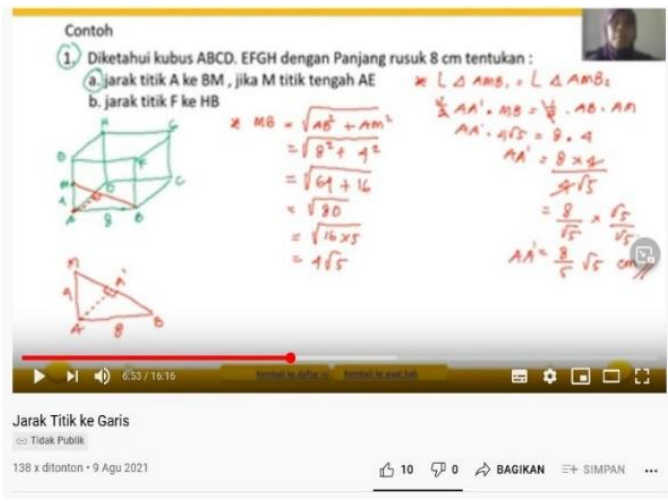

Gambar 3. Video jarak titik ke garis

Respon peserta didik terhadap video pada Gambar 2. dan Gambar 3. Dapat dilihat pada tabel 5. berikut.

Tabel 5. Respon terhadap video

\begin{tabular}{lll}
\hline Bulan & Video Pembelajaran & Frekwensi di tonton \\
\hline Juli 2021 & Jarak titik ke titik & $139 \mathrm{x}$ \\
Agsutus 2021 & Jarak titik ke garis & $138 \mathrm{x}$ \\
\hline
\end{tabular}

Tabel 5. menunjukkan respon peserta didik terhadap video pembelajaran jarak titik ke titik sebanyak $139 \mathrm{x}$ ditonton, sedangkan sebanyak $138 \mathrm{x}$ ditonton adalah respon terhadap video pembelajaran jarak titik ke garis.

\section{RESPON PESERTA DIDIK TERHADAP VIDEO}

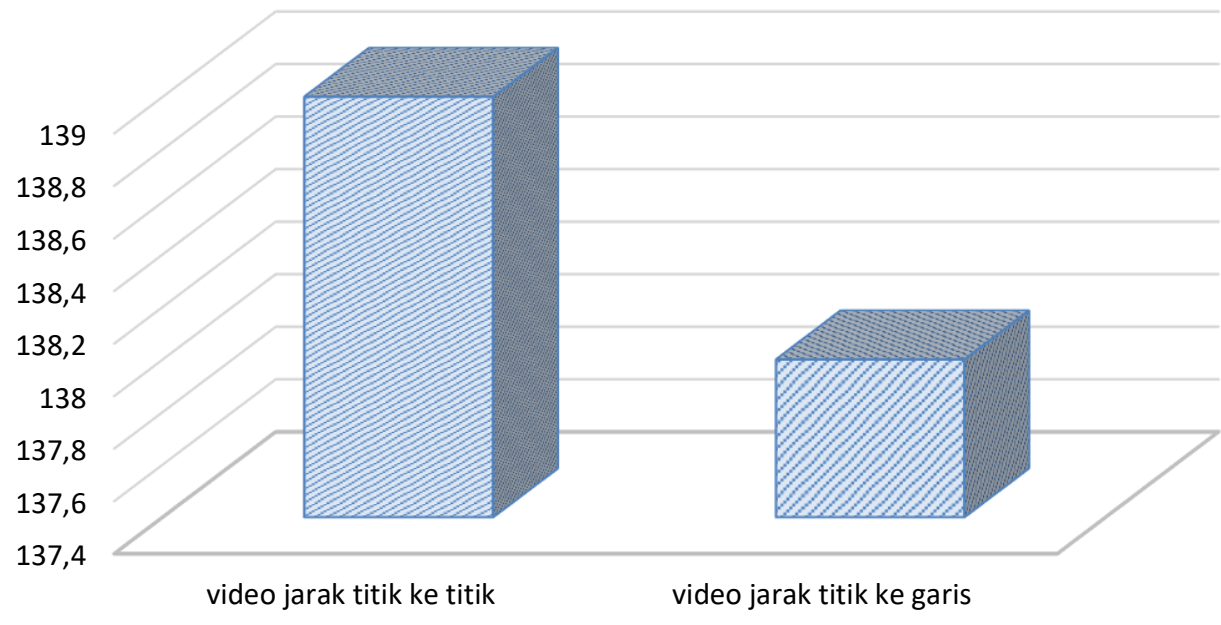

Gambar 4. Grafik Respon peserta didik terhadap video

Dari diagram batang pada grafik 4 menunjukan adanya respon positif dari masing masing video baik itu video jarak titik ke titik ataupun jarak titik ke garis dari jumlah peserta didik secara keseluruhan yang berjumlah 112 siswa, hal ini dapat dipastikan karena video 
bersifat tidak publik dan hanya bisa diakses oleh peserta didik dikelas yang mendapatkan link youtube tersebut. Hasil ini didukung dari hasil penelitian (Darson, at,el. 2020; Hanani, 2021)

3. Proses penilaian yang dilakukan selama pembelajaran jarak jauh adalah memanfaatkan google form dengan materi yang disesuaikan dengan bahan ajar pada video jarak titik ke titik dan jarak titik ke garis. Adapun soal penilaian harian nya seperti contoh pada Gambar 10 .

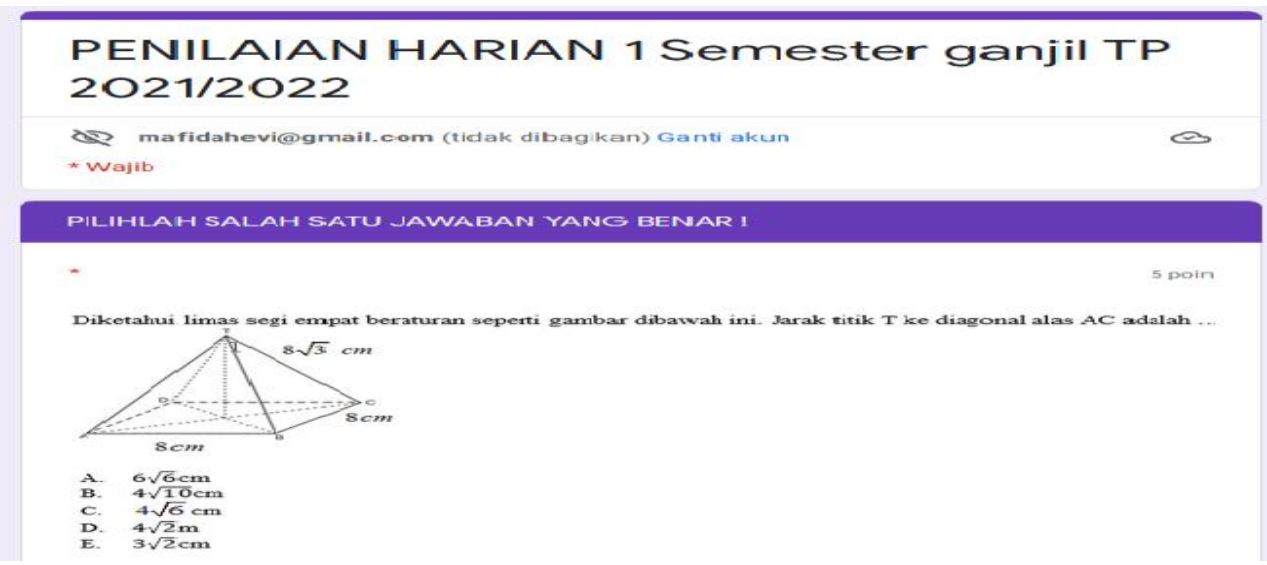

Gambar 5. Penilaian harian

Berikut adalah data rata rata hasil penilaian harian dengan google form dari hasil pembelajaran jarak jauh yang dapat dilihat pada tabel 11 dan tabel 12 dan dilaksanakan di kelas XII MIPA 4, XII MIPA 5, XII IPS 1 dan XII IPS 5.

Tabel 6. Data Rataan Nilai PH Per Kelas sebelum menggunakan video

\begin{tabular}{cllcc}
\hline No & Tanggal Pelaksanaan & Kelas & Rataan Nilai PH & Ket \\
\hline 1 & 30 Agustus 2021 & XII MIPA 4 & 50.93 & \\
2 & 30 Agustus 2021 & XII MIPA 5 & 47,4 & \\
3 & 30 Agustus 2021 & XII IPS 1 & 42,59 & \\
4 & 30 Agustus 2021 & XII IPS 5 & 41,8 & \\
& Rata rata & & 43,93 & \\
\hline
\end{tabular}

Tabel 7. Data Rataan Nilai PH Per Kelas sesudah menggunakan video

\begin{tabular}{lllcc}
\hline No & Tanggal Pelaksanaan & Kelas & Rataan Nilai PH & Ket \\
\hline 1 & 30 Agustus 2021 & XII MIPA 4 & 75,89 & \\
2 & 30 Agustus 2021 & XII MIPA 5 & 77,4 & \\
3 & 30 Agustus 2021 & XII IPS 1 & 75 & \\
4 & 30 Agustus 2021 & XII IPS 5 & 77,8 & \\
& Rata rata & & 76,5225 & \\
\hline
\end{tabular}

Tabel 8. Data Rataan nilai PH sebelum dan sesudah penggunaan video

\begin{tabular}{lllccl}
\hline No & $\begin{array}{l}\text { Tanggal } \\
\text { pelaksanaan }\end{array}$ & Kelas & $\begin{array}{c}\text { sebelum } \\
\text { penggunaan } \\
\text { video }\end{array}$ & $\begin{array}{c}\text { sesudah } \\
\text { penggunaan } \\
\text { video }\end{array}$ & Ket \\
\hline 1 & 30 Agustus 2021 & XII MIPA 4 & 50.93 & 75,89 & terlihat \\
2 & 30 Agustus 2021 & XII MIPA 5 & 47,4 & 77,4 & perubahan rata \\
3 & 30 Agustus 2021 & XII IPS 1 & 42,59 & 75 & rata nilai PH \\
4 & 30 Agustus 2021 & XII IPS 5 & 41,8 & 77,8 & setelah \\
& Rata rata & & 43,93 & 76.52 & menggunakan \\
& & & & & video \\
\hline
\end{tabular}


Dari Tabel 12. menunjukkan peningkatan rata-rata penilaian harian sebelum dan sesudah menggunakan video dari masing masing kelas, kelas XII MIPA (4) meningkat dari 50,93 menjadi 75,89, kelas XII MIPA (5) meningkat dari 47,4 menjadi 77,4, kelas XII IPS (5) naik dari 42,59 menjadi 75 dan kelas XII IPS (1) adalah meningkat dari 41,8 menjadi 77,8. Sedangkan perubahan diagram nya ditunjukkan pada Grafik 6.

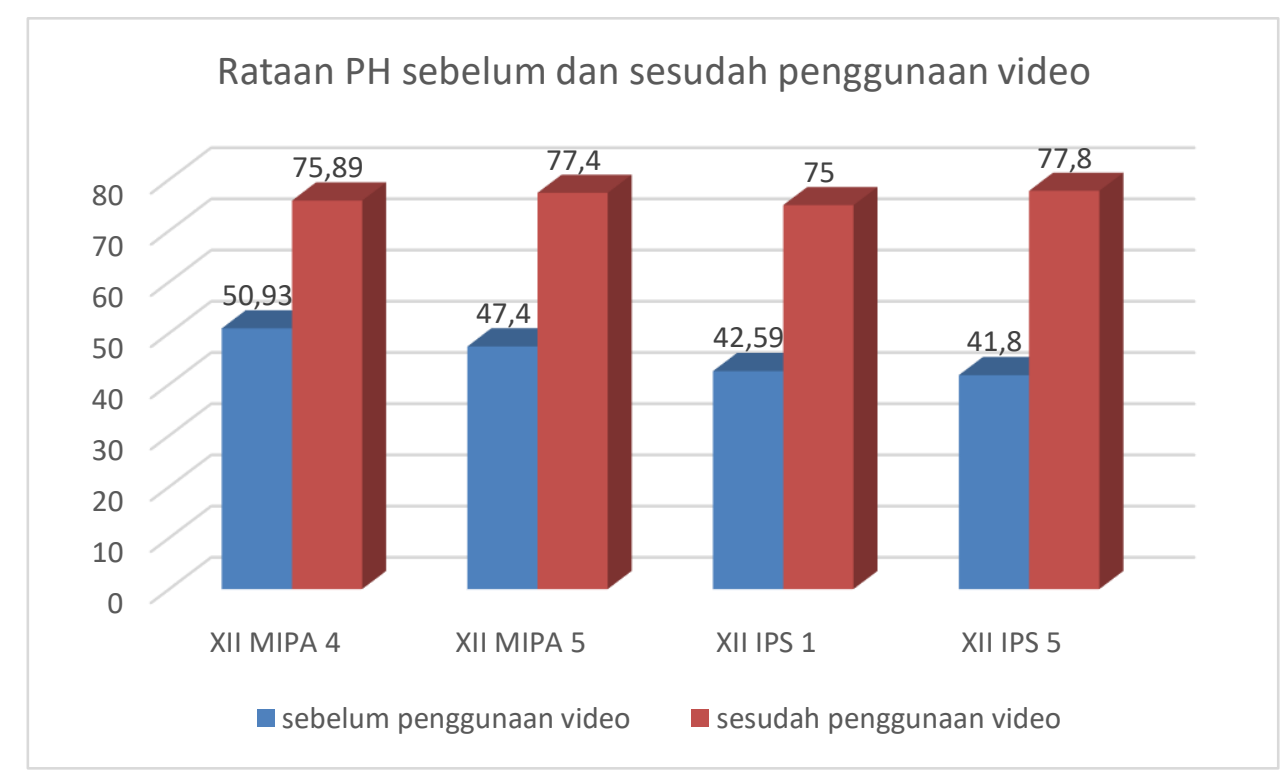

\section{Gambar 6. Grafik Rataan PH sebelum dan sesudah penggunaan video}

Gambar 6 menunjukkan bahwa diagram batang tersebut menunjukan adanya peningkatan nilai yang signifikan sesudah penggunaan video. Warna biru adalah rata sebelum penggunaan video sedangkan warna merah adalah rata rata sesudah penggunaan video. Oleh karena Kompetensi Kecapaian Minimal untuk KD 3.1 dan 4.1 adalah 75 sedangkan rata-rata nilai yang dicapai peserta setelah menggunakan video lebih besar dari 75 maka penggunaan video pembelajaran ini dapat dikatakan efektif untuk meningkatkan motivasi peserta didik dan nilai rata-rata hasil belajar. Hal ini juga didukung dari penelitian (Hanani, 2021)

\section{KESIMPULAN}

Berdasarkan uraian di atas maka dapat ditarik kesimpulan sebagai berikut.

1. Inovasi video pembelajaran dimensi tiga berbasis Pen Tablet dapat dipakai sebagai salah satu media pembelajaran jarak jauh yang efektif dan layak dijadikan best practice karena dapat meningkatkan kemampuan dalam memahami materi kedudukan titik ke titik dan titik ke garis.

2. Dengan penyusunan rencana pelaksanaan pembelajaran (RPP) daring secara sistematis dan cermat, pembelajaran jarak jauh dengan pengembangan video pembelajaran matematika materi dimensi tiga dengan menggunakan Pen Tablet dilaksanakan tidak sekadar berorientasi pada pemanfaatan teknologi, akan tetapi juga diintegrasikan dengan PPK, literasi serta disesuaikan dengan kondisi pandemi covid-19 dan kecakapan abad 21.

3. Pengembangan video ini dianggap efektif dalam pembelajaran jarak jauh karena peserta didik dapat mengikuti kelas virtual baik secara visual maupun auditorial.

\section{DAFTAR PUSTAKA}

Apriyanto, M.T. \& Herlina, L. (2020) Analisis Prestasi Belajar Matematika pada Masa Pandemi Ditinjau dari Minat Belajar Siswa. Prosiding Seminar Nasional dan Diskusi Panel Pendidikan Matematika Universitas Indraprasta PGRI, Jakarta.

Anggraeni, A. A., Nugraheni, M., \& Handayani, T. H. W. (2019). Pengembangan Video Pembelajaran Mata Kuliah Teknologi Pengawetan Makanan Materi Kacang Disko. 
Home Economics Journal, 1(1), 12-20.

Ario, M. (2019). Pengembangan video pembelajaran materi integral pada pembelajaran flipped classroom. AKSIOMA: Jurnal Program Studi Pendidikan Matematika.

Carrillo Andrés, A., Cejudo López, J. M., Domínguez Muñoz, F., \& Rodríguez García, E. A. (2013). Graphics tablet technology in second year thermal engineering teaching. Journal of Technology and Science Education, 3(3).

Darson.S, Hulukati. E., \& Djakaria. I. (2020). Pengembangan Modul dan Video Pembelajaran Matematika Persiapan Ujian Nasional pada Materi Dimensi Tiga Journal Homepage: http://ejurnal.ung.ac.id/index.php/jmathedu. Vol. 1, No. 1, pp. 21-31

Hamdan, H. Dessy, N (2016). Pemanfaatan Video sebagai Media Pembelajaran Matematika SD/MI. Journal homepage, 2(1).

Hanani. (2021). Pemanfaatan Media Pembelajaran Berbasis Video Sebagai Alternatif Dalam Pembelajaran Daring Ipa Di Mts. Negeri 1 Oku Timur. Jurnal Inovasi Pendidikan Berbantuan Teknologi, 1(2)

Maharani, N. (2021). Analisis Kebutuhan Bahan Ajar Video Berbasis Pen Tablet Dalam Pembelajaran Topik Integral Selama Pandemi Covid-19. PENDIPA Journal of Science Education, 6(1), 41-485.

Novita, R. Prahmana, R. Fajri, N. Putra, M. (2018). Penyebab kesulitan belajar geometri dimensi tiga. Jurnal Cendekia: Jurnal Riset Pendidikan Matematika 5 (1), 18-29.

Putri, N. (2021). Efektifitas Penggunaan Media video Untuk meningkatkan Pengenalan Alat Musik daerah pada pembelajaran IPS bagi Tunagrahita Ringan Di SDLB 20 Kota Solok. Jurnal Ilmiah Pendidikan Khusus, 1(2), 318-328. 